\title{
The effects of bioactive compounds on Alzheimer's disease and Mild cognitive impairment
}

\author{
Brian McAnany $^{1}$ and Danik Martirosyan ${ }^{2}$
}

${ }^{1}$ West Chester University, West Chester, PA, USA ; ${ }^{2}$ Functional Food Institute, 4659 Texas St., San Diego, CA 92116, USA

Corresponding Author: Danik M. Martirosyan, PhD, Functional Food Institute, 4659 Texas St., San Diego, CA 92116, USA

Submission Date: March 29, 2016, Accepted Date: June 18, 2016, Publication Date: June 29, 2016

\begin{abstract}
As the prevalence and rate of Alzheimer's disease are increasing around world, identifying effective treatments to manage cognitive impairment and neurodegeneration has become a global health priority. Decades of scientific research have led to a more comprehensive understanding of Alzheimer's Disease and Mild Cognitive Impairment (MCI), a transitional stage of accelerated cognitive decline. This understanding has enabled researchers to envision and develop novel Alzheimer's Disease therapies, including the use of bioactive compounds found in plants and animals. Within the past 15 years, a significant amount of clinical research has been published documenting the effects specific bioactive compounds have on patients with Alzheimer's Disease and MCI. This article reviews the results of this research, along with relevant epidemiological studies, measures of cognition, and disease pathologies to discuss whether sufficient evidence exists to support the use of specific bioactive compounds by individuals diagnosed with Alzheimer's Disease and MCI. The results of clinical trials within the last 15 years do not conclusively prove that the studied quantities of vitamin B, Omega-3 fatty acids, or bioactive compounds within Fortasyn Connect are beneficial for use in the management of Alzheimer's Disease or MCI. Additionally, the documented effects of these bioactive compounds do not warrant development of a functional food product to help manage AD or MCI.
\end{abstract}

Keywords: Bioactive compounds, Alzheimer's Disease, Mild cognitive impairment, Dementia, Vitamin B, Omega-3 fatty acids, DHA, EPA, Fortasyn Connect, Souvenaid.

\section{BACKGROUND}

Alzheimer's disease (AD) is the most common form of dementia and the most prevalent neurodegenerative disease in the world [1]. While cognitive decline is a natural part of aging, $\mathrm{AD}$ patients exhibit an unnatural level of cognitive impairment [2]. This impairment is commonly thought of as a manifestation of underlying neurodegeneration, including synaptic 
dysfunction and neuron loss. When the mean age of a population increases, the prevalence of AD is also expected to rise because $\mathrm{AD}$ is an age-associated disease [1]. Currently the mean age of the entire human population is rising, and AD is already a leading cause of death in developed countries [1,3]. Global population aging can be seen as one of humanities greatest achievements, but longer life expectancies come with inherent medical demands. Approximately 46.8 million people in the world today have Dementia. By 2030, this number is expected to reach 74.7 million [1]. Future healthcare systems will face an unprecedented demand for AD management. Fortunately, our evolving capacity to understand diet's relationship to AD may help develop novel therapies to address this health issue.

The field of functional food science seeks to understand diet's relationship with AD on a very comprehensive level. Functional food researchers study which compounds within plants and animals are responsible for specific biological effects, in addition to what dosages of these compounds produce specific effects. These compounds are referred to as bioactive compounds. In this article, this term does not apply to compounds derived from chemical synthesis. The safety and price of many bioactive compounds, relative to pharmaceuticals, makes them very interesting candidates to help manage AD. Epidemiological studies also support an association between the risk of developing $\mathrm{AD}$ and the intake of specific bioactive compounds. Within recent decades these studies have helped identify three combinations of bioactive compounds as candidates for AD Management. These three bioactive compound combinations include vitamin B, Omega-3 fatty acids, and a multi-nutrient combination named Fortasyn Connect. This article focuses exclusively on the bioactive compounds in these combinations, because unlike other compounds these compounds have been studied in multiple clinical trials that recruited patients with $\mathrm{AD}$ and MCI.

MCI is a transitional state between normal cognitive decline and AD [4]. Not all patients with $\mathrm{MCI}$ progress to $\mathrm{AD}$, but they are at a significantly higher risk to develop $\mathrm{AD}$ and experience the same protein related neurodegeneration as $\mathrm{AD}$ patients $[4,5]$. Candidate $\mathrm{AD}$ therapies have been tested on both MCI and AD patients due to their shared pathomechanisms and accelerated rates of cognitive decline. This article reviews the results of recent clinical trials that utilized the three mentioned bioactive compound combinations to manage cognitive decline and neurodegeneration in patients with $\mathrm{AD}$ and MCI. This article also discusses whether the results of these trials supply the necessary evidence for future development of a functional food product.

\section{Retrieval of Published Studies}

Electronic searches of published studies were conducted utilizing PubMed®, and EBSCOhost. Both review and research papers were included. No language limitations were imposed. A publication date limitation was imposed when clinical trials were retrieved. All clinical trials searched were limited to following rage of years 2000-2016. Keywords for the search included: Alzheimer's Disease, Mild cognitive impairment, Dementia, Clinical trials, vitamin B, Folic acid, B12, B6 Omega-3 fatty acids, DHA, EPA, Fortasyn Connect, Souvenaid, Bioactive food compounds, Epidemiological, Amyloid Beta, Tau, Pathology, Mechanisms, Neurodegeneration, Cognitive examinations, MMSE, ADAS, Neuroimaging, MRI. 


\section{Epidemiologic Studies of Patients with Dementia and Cognitive Impairment}

Much of the recent $\mathrm{AD}$ research involving bioactive compounds is a product of initial epidemiologic findings. In fact, several of the clinical trials we reviewed cited the same studies originally reported these findings [Error! Bookmark not defined.-Error! Bookmark not defined.]. These initial studies discovered differences between the plasma profiles and nutrient intakes of demented patients and healthy controls. These differences were uncovered through the utilization of two basic study designs. In the first study design, researchers recorded the characteristics of patients diagnosed with $\mathrm{AD}$ and $\mathrm{MCI}$, and compared those characteristics to healthy controls. Differences between group characteristics were thought to be associated with $\mathrm{AD}$ and MCI. In studies of this nature, researchers found that $\mathrm{AD}$ patients exhibited higher plasma levels of homocysteine, and lower plasma levels of vitamin B and Omega-3 fatty acids when compared to controls [Error! Bookmark not defined.-13]. In the second study design, researchers recorded the characteristics of non-diseased individuals, and followed them for a significant amount of time to allow for a portion of the sample to receive an AD or dementia diagnosis. Similarities in characteristics of individuals later diagnosed were investigated as potential risk factors, while similarities in characteristics of individuals who remained healthy were investigated as potential protective factors. In studies of this nature, researchers discovered that participants with lower vitamin B and Omega-3 fatty acid status and higher baseline plasma homocysteine levels were at a significantly higher risk of developing Dementia [Error! Bookmark not defined., Error! Bookmark not defined.]. Individuals who consumed fish more frequently or had a higher intake of Omeg-3 fatty acids were at a significantly lower risk of developing Dementia [Error! Bookmark not defined.-Error! Bookmark not defined.]. Investigators theorized that the high Omega-3 Fatty acid content of fish was responsible for the apparent protective effects of frequent fish consumption. The results of the epidemiological studies listed above have not been reproduced throughout all of the literature, making the epidemiological evidence for the use of bioactive compounds by $\mathrm{AD}$ and MCI patients controversial [6-8].

\section{Possible neurodegenerative mechanisms in Alzheimer's disease and Mild cognitive impairment}

All cognitive ability reflects the brain's functionality on a physical level, as this physical level is where neurodegeneration from $\mathrm{AD}$ and MCI pathology occurs. Our current understanding of many neurodegenerative mechanisms can be traced back to the psychiatrist Alois Alzheimer. In 1906, Alzheimer identified two types of insoluble protein aggregates, now known as Amyloid Beta (A $\boldsymbol{\beta}$ ) plaques and Neurofibrillary tangles (NFT), in the brain of a cognitively impaired patient [9]. Since Alzheimer's initial discovery, over a hundred years of research has further developed our understanding of these disease related proteins. Amyloid Beta (A $\boldsymbol{\beta})$ plaques predominantly consist of A $\boldsymbol{\beta}$ protein, and NFT's predominantly consist of tau protein, today both $\mathrm{A} \boldsymbol{\beta}$ and tau proteins are considered central to $\mathrm{AD}$ and $\mathrm{MCI}$ pathology. Healthy neurons produce $\mathrm{A} \boldsymbol{\beta}$ and Tau protein, but abnormal events render these proteins neurotoxic [20,21]. Each of these proteins have a monomeric, oligomeric and fibrillar form which behave in distinctly different 
ways. It is easier to explain the roles these proteins play in disease related neurodegeneration separately as both proteins undergo separate aggregation processes.

The three forms of $\mathrm{A} \boldsymbol{\beta}$ protein relevant to $\mathrm{AD}$ are $\mathrm{A} \boldsymbol{\beta}$ monomers, $\mathrm{A} \boldsymbol{\beta}$ oligomers and $\mathrm{A} \boldsymbol{\beta}$ plaques. All three of these forms contain A $\boldsymbol{\beta}$ protein, which was initially created from the proteolysis of Amyloid precursor protein (APP) [Error! Bookmark not defined., 22]. A $\boldsymbol{\beta}$ monomers are proteolytically cleaved off APP into the extracellular space of a neuron [Error! Bookmark not defined., Error! Bookmark not defined.]. The creation and subsequent clearance of $\mathrm{A} \boldsymbol{\beta}$ monomers occurs in healthy brain tissue, however, in diseased brain tissue; an imbalance between $\mathrm{A} \boldsymbol{\beta}$ monomer production and clearance leads to an excess amount of $\mathrm{A} \boldsymbol{\beta}$ monomers. Un-cleared or overproduced $A \boldsymbol{\beta}$ monomers may then aggregate into toxic $\mathrm{A} \boldsymbol{\beta}$ oligomers [Error! Bookmark not defined., 13]. The oligomeric form of A $\boldsymbol{\beta}$ protein is considered by many to be the most neurotoxic form of A $\boldsymbol{\beta}$ protein. A $\boldsymbol{\beta}$ oligomers travel to the intercellular space of neurons and disrupt cellular processes, which leads to cell death [Error! Bookmark not defined., Error! Bookmark not defined.]. A $\boldsymbol{\beta}$ oligomers that remain in the extracellular space and aggregate form large masses of A $\boldsymbol{\beta}$ protein called A $\boldsymbol{\beta}$ plaques [Error! Bookmark not defined.-Error! Bookmark not defined.]. A $\boldsymbol{\beta}$ plaques are insoluble forms of the $A \boldsymbol{\beta}$ protein that cannot move into the intercellular space of a neuron. [Error! Bookmark not defined., Error! Bookmark not defined.].

The second protein central to AD and MCI pathology is the tau protein. Three AD-related forms of tau protein include hyper-phosphorylated tau monomers, tau oligomers, and neurofibrillary tangles (NFT). Tau protein is often referred to as a microtubule associated protein, because tau protein stabilizes the structure of microtubules in the axon of a neuron [2417]. In the axon of diseased neurons, tau protein becomes abnormally phosphorylated and dislocates from the microtubules, generating untethered tau monomers [Error! Bookmark not defined.-18]. Current theories associate this dislocation with microtubule dysfunction, leading to mitochondrial dysfunction, synaptic dysfunction, and ultimately cell death [Error! Bookmark not defined.-17]. Untethered tau monomers circulating in the intercellular space may aggregate to form tau oligomers [Error! Bookmark not defined., Error! Bookmark not defined.]. Researchers believe the oligomeric form of tau protein can travel to other neurons and propagate the destabilization of tau in foreign axons. The potential for tau oligomers to spread tau pathology is why many consider the oligomeric form of tau to be the most toxic [17]. Tau oligomers that remain inside a neuron's intracellular space may aggregate together to form filaments, which can further aggregate into the large insoluble masses of tau protein known as NFT's [11, 19]. There is not much evidence supporting that NFTs or A $\boldsymbol{\beta}$ plaques directly contribute to neurodegeneration the way lower order aggregates of tau and A $\boldsymbol{\beta}$ protein do; nonetheless, they remain some of the most visually pronounced results of $\mathrm{AD}$ and $\mathrm{MCI}$ pathology $[13,17]$.

\section{Possible Effects of Bioactive Compounds on Alzheimer's disease and Mild cognitive impairment}

There are many theories describing how vitamin B, Omega-3 fatty acids, and the bioactive compounds within Fortasyn Connect, mitigate the neurotoxic effects of both $\mathrm{A} \boldsymbol{\beta}$ and tau protein. 
The theory most cited throughout the trials reviewed states that specific bioactive compounds may positively affect the health of neuronal membranes, increasing a neuron's resistance to disease-related neurodegeneration [20,21]. Neuronal membranes are continuously formed and maintained, requiring an adequate stock of neuronal membrane precursors and cofactors [20]. Hypothetically, a suboptimal stock of compounds could lead to suboptimal neuronal membrane health. Furthermore, an individual with poor neuronal membrane health may sustain more damage from the $\mathrm{AD}$ related neurotoxic agents. The bioactive compounds within the vitamin $\mathrm{B}$, Omega-3 fatty acid, and the Fortasyn Connect combinations, are supplemented to increase a deficient individuals stock of neuronal membrane precursors or cofactors and restore adequate neuronal membrane health $[20,21]$. Theoretically the restoration of adequate neuronal membrane health will improve the individual's resistance to disease-related neurodegeneration. This theory regarding improved neuronal membrane health and resistance to neurodegeneration has also provided the basis for several bioactive compounds proposed effects on cognition.

\section{Measures of Cognition and Neurodegeneration}

The cognitive outcomes of the participants in the reviewed clinical trials were assessed by the use of cognitive examinations. There are two main types of cognitive examination. The first type examines overall cognitive ability by testing a subjects performance in a large set of mental functions such as memory, perception, attention, language, visual and spatial processing, and executive functions [22]. The results of these examinations are used as diagnostic criteria for AD and MCI. One of the most widely used overall cognitive examinations in clinical research is the Mini-Mental State Examination (MMSE). The MMSE assesses a subject's attention, memory, language and several other mental abilities through a 30 point questionnaire to determine an overall evaluation of mental state [22]. Many of the studies we reviewed utilized MMSE scores as inclusion/exclusion criteria and/or a measurable cognitive outcome. Another commonly used overall cognitive examinations is the Alzheimer's Disease Assessment Scale-Cognitive subscale (ADAS-cog). The ADAS-cog is a 11 item evaluation originally designed to assess cognitive impairment in AD patients [23]. Since its inception the function of the ADAS-cog has expanded, assessing cognitive impairment at levels insufficient to bring about a AD diagnosis. ADAS-cog scores are currently being utilized to determine Mild Cognitive Impairment [23]. The second type of cognitive examination tests a subject's performance on one or few specific cognitive functions. Studies often use this type of examination, in addition to those of overall cognitive ability, to more comprehensively assess a subject's cognitive abilities. Many of the specific cognitive function examinations have non-intuitive abbreviated names. Throughout the text the specific cognitive function being examined is displayed adjacent to these abbreviations in parenthesis. Neither type of cognitive examination quantifies physical neurodegeneration, but instead are believed to record the cognitive ramifications of neuronal damage.

Throughout the clinical trials reviewed, the only assessment used to quantify physical neurodegeneration was Magnetic Resonance Imaging (MRI). MRI's create a detailed structural image of the brain providing valuable information regarding the effects of $\mathrm{AD}$ and $\mathrm{MCI}$ pathology on specific structures [24]. Although MRI's cannot detect the presence of A $\boldsymbol{\beta}$ plaques and NFTs, they can be used to both precisely measure reductions in brain matter volume, and calculate rates of brain atrophy. The volumetric reductions of brain matter seen in patients with 
$\mathrm{AD}$ and MCI is thought to predominantly reflect the loss of neurons and dendrites [24]. The ability for MRI's to show physical degeneration has been exceedingly valuable in clinical research [25].

\section{Vitamin B in Clinical Trials}

The vitamin B nutrient combination consists of three bioactive compounds: B6, B12, and folic acid. In the past 15 years, five research papers were published that documented the effects of B vitamin supplementation patients diagnosed with $\mathrm{AD}$ and MCI. The study designs and results of all reviewed vitamin B clinical trials are indexed in Table 1. These investigations measured B vitamin supplementation's, safety and tolerability, capacity to decrease plasma levels of homocysteine, and effect on disease related cognitive decline and neurodegeneration. It must be mentioned that three of the five research papers investigated the same sample of MCI patents, denoted in table one by the term VITACOG trial [26-28].

Vitamin B supplementation was not associated with serious adverse effects throughout the majority of the literature. However, one trial reported a higher number of depression related adverse effects in the vitamin B group [30]. Two separate clinical trials successfully reduced the levels of plasma homocysteine with vitamin B supplementation. The VITACOG trial's invention consisting of $0.5 \mathrm{mg} / \mathrm{d}$ of B12, $20 \mathrm{mg} / \mathrm{d}$ of B6, and $0.8 \mathrm{mg} / \mathrm{d}$ of folic acid reduced plasma homocysteine (tHcy) levels by $23 \%$ [26]. The Aisen et al RCT's invention consisting of $1 \mathrm{mg} / \mathrm{d}$ of B12, $25 \mathrm{mg} / \mathrm{d}$ of B6, and $5 \mathrm{mg} / \mathrm{d}$ of folic acid reduced plasma tHcy levels by 27\% [29]. The VITACOG trial produced the only positive effects on cognitive performance of the trials reviewed. Independent of baseline plasma tHcy levels the VITACOG trial's intervention reportedly stabilized CLOX test (executive function) performance, but did not improve performance in measures of global cognitive function, memory, or clinical status [27]. The intervention group of the VITACOG trial also demonstrated reductions in the rate of whole brain atrophy and total 2-year gray matter loss independent of baseline plasma tHcy levels [26,28]. VITACOG trial participants taking vitamin B with higher than median baseline plasma tHcy level exhibited greater cognitive improvements and greater reductions in brain atrophy. Despite the positive cognitive effects seen within the VITACOG trial's vitamin B group, no positive effects were seen on measures of cognition in the other two clinical trial samples [Error! Bookmark not defined.,30]. No other trial reviewed besides the VITACOG trial measured brain atrophy outcomes.

Table 1. The effects of vitamin B on AD and MCI

\begin{tabular}{|c|c|c|c|c|}
\hline Study & Participants & Intervention & Duration & Outcome \\
\hline $\begin{array}{l}\text { Smith AD, } \\
2010 \\
{[26]} \\
\text { Randomized } \\
\text { controlled } \\
\text { trial }\end{array}$ & $\begin{array}{l}271 \\
\text { individuals } \\
\text { aged } 70 \text { years } \\
\text { old or older } \\
\text { diagnosed } \\
\text { with MCI }\end{array}$ & $\begin{array}{l}0.5 \mathrm{mg} \text { of } \\
\mathrm{B} 12 \text {, } \\
20 \mathrm{mg} \text { of } \mathrm{B} 6 \text {, } \\
\text { and } \\
0.8 \mathrm{mg} \text { of } \\
\text { Folic acid was } \\
\text { taken daily. }\end{array}$ & 24 months & $\begin{array}{l}\text { A subsample of } 168 \text { individuals completed the MRI } \\
\text { portion of the trial. Independent of baseline tHcy levels the } \\
\text { rate of whole brain atrophy in the vitamin B group was } \\
27.1 \% \text { less per year compared to control group. The rate of } \\
\text { whole brain atrophy in the vitamin B group was } 53.3 \% \\
\text { less per year compared to control group for individuals } \\
\text { with baseline tHcy levels of }>13 \mu \mathrm{mol} / \mathrm{L} \\
\text { After } 24 \text { months the vitamin group B experienced a } 22.5 \\
\% \text { reduction in plasma tHcy levels, and the placebo group }\end{array}$ \\
\hline
\end{tabular}




\begin{tabular}{|c|c|c|c|c|}
\hline Study & Participants & Intervention & Duration & Outcome \\
\hline & & & & experienced a increase in plasma tHcy levels of $7.7 \%$. \\
\hline $\begin{array}{l}\text { de Jager } \\
\text { CA, } 2012 \\
{[27]} \\
\text { Randomized } \\
\text { controlled } \\
\text { trial }\end{array}$ & $\begin{array}{l}\text { VITACOG } \\
266 \\
\text { individuals } \\
\text { aged } 70 \text { years } \\
\text { old or older } \\
\text { diagnosed } \\
\text { with MCI }\end{array}$ & $\begin{array}{l}\text { VITACOG } \\
0.5 \mathrm{mg} \text { of } \\
\mathrm{B} 12, \\
20 \mathrm{mg} \text { of } \mathrm{B} 6, \\
\text { and } \\
0.8 \mathrm{mg} \text { of } \\
\text { Folic acid was } \\
\text { taken daily. }\end{array}$ & 24 months & $\begin{array}{l}\text { Independent of baseline tHcy, vitamin B stabilized CLOX } \\
\text { Test performance, but did not improve performance in } \\
\text { measures of global cognitive function, episodic memory, } \\
\text { semantic memory, or clinical status. In subjects with a } \\
\text { baseline plasma tHcy level of } \geq 11.3 \mu \mathrm{mol} / \mathrm{L} \text {, vitamin B } \\
\text { supplementation had a beneficial effect on measures of } \\
\text { episodic memory, semantic memory, and global cognitive } \\
\text { function. In subjects with a baseline plasma tHcy level of } \\
\geq 13.1 \mu \mathrm{mol} / \mathrm{L} \text {, vitamin B supplementation improved } \\
\text { clinical status (CDR and IQCODE) compared to controls. }\end{array}$ \\
\hline $\begin{array}{l}\text { Douaud G, } \\
2013 \\
\text { [28] } \\
\text { Randomized } \\
\text { controlled } \\
\text { trial }\end{array}$ & $\begin{array}{l}\text { VITACOG } \\
156 \\
\text { individuals } \\
\text { aged } 70 \text { years } \\
\text { old or older } \\
\text { diagnosed } \\
\text { with MCI }\end{array}$ & $\begin{array}{l}\text { VITACOG } \\
0.5 \mathrm{mg} \text { of } \\
\mathrm{B} 12, \\
20 \mathrm{mg} \text { of } \mathrm{B} 6, \\
\text { and } \\
0.8 \mathrm{mg} \text { of } \\
\text { Folic acid was } \\
\text { taken daily. }\end{array}$ & 24 months & $\begin{array}{l}\text { Subjects with a baseline plasma tHcy level of } \leq 11.6 \\
\boldsymbol{\mu} \text { mol/L, received no benefit from vitamin B } \\
\text { supplementation on the volume of total grey matter lost. } \\
\text { Vitamin B supplementation significantly reduced the } \\
\text { amount of grey matter atrophy compared to placebo in } \\
\text { subjects with a baseline plasma tHcy level of }>11.6 \\
\boldsymbol{\mu} \text { mol/L. Within this higher baseline plasma tHcy } \\
\text { subsample, subjects taking the placebo sustained an } \\
\text { average total gray matter volume loss of } 5.2 \% \text { and subjects } \\
\text { taking vitamin B showed an average total gray matter } \\
\text { volume loss of } 0.6 \% \text {. }\end{array}$ \\
\hline $\begin{array}{l}\text { Aisen PS, } \\
2008 \\
{[29]} \\
\text { Randomized } \\
\text { controlled } \\
\text { trial }\end{array}$ & $\begin{array}{l}409 \\
\text { individuals } \\
\text { diagnosed } \\
\text { with mild to } \\
\text { moderate AD. }\end{array}$ & $\begin{array}{l}1 \mathrm{mg} \text { of B12, } \\
25 \mathrm{mg} \text { of B6, } \\
\text { and } \\
5 \mathrm{mg} \text { of Folic } \\
\text { acid was taken } \\
\text { daily. }\end{array}$ & 18 months & $\begin{array}{l}\text { Vitamin B supplementation had no beneficial effect on } \\
\text { subjects ADAS-cog, MMSE, and CDR-SOB scores. After } \\
18 \text { months the vitamin B group experienced a } 27 \% \\
\text { reduction in plasma tHcy levels, and the placebo group } \\
\text { experienced a } 7 \% \text { reduction in plasma tHcy levels. }\end{array}$ \\
\hline $\begin{array}{l}\text { van Uffelen } \\
\text { J, 2008 } \\
\text { [30] } \\
\text { Randomized } \\
\text { controlled } \\
\text { trial }\end{array}$ & $\begin{array}{l}152 \\
\text { individuals } \\
\text { aged between } \\
70 \text { and } 80 \\
\text { years } \\
\text { diagnosed } \\
\text { with MCI }\end{array}$ & $\begin{array}{l}0.4 \mathrm{mg} \text { of } \\
\mathrm{B} 12 \text {, } \\
50 \mathrm{mg} \text { of } \mathrm{B} 6 \text {, } \\
\text { and } \\
5 \mathrm{mg} \text { of Folic } \\
\text { acid was taken } \\
\text { daily. }\end{array}$ & 12 months & $\begin{array}{l}\text { Vitamin B supplementation had no beneficial effect on } \\
\text { measures of memory, attention, executive function, and } \\
\text { information processing. Vitamin B's effect on plasma } \\
\text { tHcy levels was not analyzed. }\end{array}$ \\
\hline
\end{tabular}

\section{Omega-3 Fatty Acids in Clinical Trials}

The Omega-3 Fatty Acid combination that was utilized the most to manage AD consisted of two bioactive compounds, docosahexanoic acid (DHA) and eicosapentaenoic acid (EPA). In the past 15 years, there have been six comparable clinical trials that document the effects that Omega-3 Fatty Acid supplementation has on patients diagnosed with AD and MCI. The study designs and results of all reviewed Omega-3 fatty acid clinical trials are indexed in Table 2. These investigations measured Omega-3 Fatty Acid supplementation's, safety and tolerability, capacity to increase DHA and EPA status, and effect on disease related cognitive decline and neurodegeneration. It should be noted that the Quinn et al 2010 randomized controlled trial (RCT) was supplemented with only DHA. All other trials utilized both DHA and EPA in their investigations [31].

Throughout the majority of studies reviewed, Omega-3 fatty acid supplementation was described as well tolerated and safe. The few adverse effects reported across these studies were 
described as mild and gastrointestinal by nature [33, 35]. Omega-3 fatty acid supplementation increased plasma, serum, or erythrocyte levels of DHA and EPA in several different dosages. Additionally, the Quinn et al 2010 RCT reported that a $2000 \mathrm{mg}$ supplement $45-55 \%$ DHA by weight, significantly increased the levels DHA within the cerebrospinal fluid [31]. The amount of DHA and EPA given in these trials varied; daily doses of DHA ranged between $650 \mathrm{mg}-1700$ $\mathrm{mg}$, and daily doses of EPA ranged between $450 \mathrm{mg}-1080 \mathrm{mg}$ [31-36]. Although Omega-3 fatty acid supplementation had positive effects on subject's DHA and EPA status, it failed to produce positive effect on the scores of overall cognition, independent of baseline cognitive impairment [31-36]. This lack of effect on cognition was especially significant, because it was reproduced in several different trials utilizing the ADAS-cog and MMSE examinations [31-36]. Only subsamples with a lower level of baseline cognitive impairment showed improvements in overall cognitive ability [34, 35]. Independent of baseline cognitive impairment, Omega-3 fatty acid did have a beneficial effect on measures of specific cognitive function [33-35]. Unfortunately, none of these specific cognitive function improvements were reproduced utilizing the same test in more than one study. Finally the Quinn et al 2010 RCT tested DHA supplementation's effect on the rates of brain atrophy, but no difference was seen between the DHA intervention group and the placebo group [31].

Table 2. The effects of Omega-3 fatty acids on AD and MCI

\begin{tabular}{|c|c|c|c|c|}
\hline Study & Participants & Intervention & Duration & Outcomes \\
\hline $\begin{array}{l}\text { Quinn JF, } 2010 \\
\text { [31] } \\
\text { Randomized, } \\
\text { double-blind, } \\
\text { placebo- } \\
\text { controlled trial }\end{array}$ & $\begin{array}{l}402 \text { individuals } \\
\text { diagnosed with } \\
\text { mild to moderate } \\
\text { AD }\end{array}$ & $\begin{array}{l}2000 \mathrm{~g} \text { of Algal DHA, } \\
(45 \%-55 \% \text { DHA by } \\
\text { weight) was taken daily. }\end{array}$ & 18 months & $\begin{array}{l}\text { DHA supplementation had no } \\
\text { beneficial effect on ADAS-cog or } \\
\text { CDR sum of boxes scores. In a } \\
\text { subsample of } 102 \text { participant's MRIs } \\
\text { revealed no difference in the rate of } \\
\text { brain atrophy between DHA group } \\
\text { and placebo group. }\end{array}$ \\
\hline $\begin{array}{l}\text { Phillips M, } 2015 \\
\text { [32] } \\
\text { Randomized, } \\
\text { double-blind, } \\
\text { placebo- } \\
\text { controlled trial }\end{array}$ & $\begin{array}{l}76 \text { individuals } \\
\text { diagnosed with } \\
\text { either Alzheimer's } \\
\text { disease, or CIND } \\
\text { (Cognitive } \\
\text { Impairment No } \\
\text { Dementia). }\end{array}$ & $\begin{array}{l}625 \mathrm{mg} \text { of DHA and } \\
600 \mathrm{mg} \text { of EPA was } \\
\text { taken daily. }\end{array}$ & 4 months & $\begin{array}{l}\text { The Omega- } 3 \text { supplementation had no } \\
\text { beneficial effect on cognitive function } \\
\text { based on MMSES7, MMSEWB } \\
\text { scores, and three separate verbal } \\
\text { memory examinations. }\end{array}$ \\
\hline $\begin{array}{l}\text { Lee LK, } 2012 \\
\text { [33] } \\
\text { Randomized, } \\
\text { double-blind, } \\
\text { placebo- } \\
\text { controlled trial }\end{array}$ & $\begin{array}{l}36 \text { individuals } \\
\text { aged } 60 \text { years or } \\
\text { older diagnosed } \\
\text { with MCI and low } \\
\text { socioeconomic } \\
\text { status. }\end{array}$ & $\begin{array}{l}1300 \mathrm{mg} \text { of DHA and } \\
450 \mathrm{mg} \text { of EPA, was } \\
\text { taken daily. }\end{array}$ & 12 months & $\begin{array}{l}\text { No difference was seen between } \\
\text { omega-3 and placebo group scores, on } \\
\text { MMSE, CDT, GDS, visual } \\
\text { reproduction II, RAVLT total } \\
\text { immediate recall, block design, digit } \\
\text { symbol substitution, and matrix } \\
\text { reasoning. } \\
\text { Omega-3 supplementation had a } \\
\text { beneficial effect the following specific } \\
\text { cognitive function examinations } \\
\text { compared to placebo, digit span, } \\
\text { visual reproduction I, and RAVLT } \\
\text { delayed recall. }\end{array}$ \\
\hline Freund-Levi Y, & 204 individuals & $1700 \mathrm{mg}$ of DHA and & 12 months & At 6 months there was no difference \\
\hline
\end{tabular}




\begin{tabular}{|c|c|c|c|c|}
\hline Study & Participants & Intervention & Duration & Outcomes \\
\hline $\begin{array}{l}2006 \\
\text { [34] } \\
\text { Randomized, } \\
\text { double-blind, } \\
\text { placebo- } \\
\text { controlled } \\
\text { clinical trial. }\end{array}$ & $\begin{array}{l}\text { diagnosed with } \\
\text { mild to moderate } \\
\text { AD }\end{array}$ & $\begin{array}{l}600 \mathrm{mg} \text { of EPA acid } \\
\text { was taken daily. } 4 \mathrm{mg} \text { of } \\
\text { vitamin } \mathrm{E} \text { taken daily by } \\
\text { all groups. } \\
\text { At month } 6 \text { placebo } \\
\text { group began taking } \\
\text { Omega- } 3 \text { supplement, } \\
\text { and Omega- } 3 \text { group } \\
\text { continued to take } \\
\text { Omega- } 3 \text { supplement. }\end{array}$ & & $\begin{array}{l}\text { between the MMSE or ADAS-cog } \\
\text { scores of the Omega- } 3 \text { and placebo } \\
\text { group. At } 12 \text { months there was no } \\
\text { difference seen in MMSE or ADAS- } \\
\text { cog scores between the Omega- } \\
\text { 3/Omega- } 3 \text { group and } \\
\text { Placebo/Omega- } 3 \text { group. } \\
\text { At } 6 \text { months in subgroups with very } \\
\text { mild cognitive impairment, Omega-3 } \\
\text { supplementation had a beneficial } \\
\text { effect on MMSE scores, compared to } \\
\text { the placebo. }\end{array}$ \\
\hline $\begin{array}{l}\text { Chiu C-C, } 2008 \\
\text { [35] } \\
\text { Randomized } \\
\text { double-blind } \\
\text { placebo- } \\
\text { controlled study }\end{array}$ & $\begin{array}{l}46 \text { individuals } \\
\text { diagnosed with } \\
\text { either MCI or } \\
\text { mild to moderate } \\
\text { AD between the } \\
\text { ages of } 55 \text { and } 90 \\
\text { years old. }\end{array}$ & $\begin{array}{l}720 \mathrm{mg} \text { of DHA and } \\
1080 \mathrm{mg} \text { of EPA was } \\
\text { taken daily }\end{array}$ & 24 weeks & $\begin{array}{l}\text { There was no difference observed in } \\
\text { ADAS-cog, MMSE, and HDRS scores } \\
\text { between groups. } \\
\text { Omega-3 supplementation had a } \\
\text { beneficial effect on CIBIC-plus scores } \\
\text { compared to placebo. In subgroups } \\
\text { with MCI, Omega- } 3 \text { supplementation } \\
\text { had a beneficial effect on ADAS-cog } \\
\text { scores compared to placebo. }\end{array}$ \\
\hline $\begin{array}{l}\text { Shinto L, } 2014 \\
\text { [36] } \\
\text { Randomized } \\
\text { Placebo- } \\
\text { Controlled Pilot } \\
\text { Trial }\end{array}$ & $\begin{array}{l}39 \text { individuals } \\
\text { diagnosed with } \\
\text { probable AD aged } \\
55 \text { years or older. }\end{array}$ & $\begin{array}{l}\text { Omega- } 3 \text { group was } \\
\text { given } 675 \mathrm{mg} \text { of DHA } \\
\text { and } 975 \mathrm{mg} \text { of EPA } \\
\text { daily } \\
\text { Linoleic group was } \\
\text { given } 675 \mathrm{mg} \text { of DHA, } \\
975 \mathrm{mg} \text { of EPA, and } \\
600 \mathrm{mg} \text { of LA daily }\end{array}$ & 12 months & $\begin{array}{l}\text { There was no difference observed in } \\
\text { ADAS-cog and ADL scores between } \\
\text { groups. } \\
\text { Both Omega- } 3 \text { group and Linoleic } \\
\text { group showed a lower amount of } \\
\text { decline in IADL scores. } \\
\text { Linoleic group showed a lower } \\
\text { amount of decline in MMSE scores } \\
\text { compared to both Omega-3 group and } \\
\text { placebo. }\end{array}$ \\
\hline
\end{tabular}

\section{Fortasyn Connect Nutrient Combination in Clinical Trials}

The Fortasyn Connect nutrient combination consists of several bioactive compounds: Omega-3 fatty acids, vitamin B, Phospholipids, Choline, Uridine, Selenium, Vitamin E, and Vitamin C. In the past 15 years, there have been three comparable clinical trials that document the effects Fortasyn Connect has on patients diagnosed with AD and MCI. The study designs and results of all reviewed Fortasyn Connect clinical trials are indexed in Table 3. The trademarked Fortasyn Connect nutrient combination was administered in the form of the medical food Souvenaid, and the specific quantities of bioactive compounds within Souvenaid are listed directly below Table 3. The three investigations documented Souvenaid supplementation's, safety and tolerability, capacity to influence plasma levels of targeted nutrients, and effect on disease related cognitive decline. The daily amount of Souvenaid given to participants was the same throughout all of the reviewed trials.

All trials concluded that Souvenaid containing the Fortasyn Connect nutrient profile had a high level of safety and tolerability [37-40]. Souvenaid supplementation also consistently influenced erythrocyte and plasma levels of target nutrients. In all three trials, Souvenaid increased omega3-fatty acids and vitamin E status, and decreased plasma tHcy levels [38-40]. Souvenaid's effect on AD-related cognitive decline was assessed by a variety of measures, including standardized cognitive examinations, a Neuropsychiatric inventory, a 
Neuropsychological Test Battery (NTB), and Electroencephalography (EEG). In the Souvenir I trial, Souvenaid supplementation had no beneficial effects on examinations of overall cognitive ability or a 12 point Neuropsychiatric inventory, but was associated with improved performance in delayed verbal recall testing [38]. In the Souvenir II study, the Souvenaid group's NTB memory domain Z-scores improved compared to control, but there was no difference reported in NTB executive function domain Z-scores between groups [39]. The Souvenir II study also utilized EEG data to measure participant's functional brain connectivity. EEG analysis revealed a positive difference in the Souvenaid group's delta frequency band trajectory over the 24-week treatment period compared to the control group [39]. No such difference was observed in any other frequency bands. Lastly, the Shah et al 2013 RCT concluded that there were no differences in ADAS-cog scores between the experimental group and the placebo group [40].

Table 3. The effects of the Fortasyn Connect nutrient combination on AD and MCI

\begin{tabular}{|c|c|c|c|c|}
\hline Study & Participants & Intervention & Duration & Outcome \\
\hline $\begin{array}{l}\text { Scheltens P, } 2010 \\
\text { [38] } \\
\text { Souvenir I } \\
\text { Randomized } \\
\text { controlled trial }\end{array}$ & $\begin{array}{l}225 \text { drug-naïve } \\
\text { individuals mild AD } \\
\text { aged } 50 \text { years or } \\
\text { older. }\end{array}$ & $\begin{array}{l}125 \mathrm{ml} \text { of } \\
\text { Souvenaid was } \\
\text { taken daily }\end{array}$ & 12 weeks & $\begin{array}{l}\text { Souvenaid supplementation had a } \\
\text { beneficial effect on delayed verbal } \\
\text { recall testing. No difference was } \\
\text { observed between group scores on } \\
\text { modified ADAS-cog, CIBIC-plus, } \\
\text { ADCS-ADL, and } 12 \text { item } \\
\text { Neuropsychiatric inventory. }\end{array}$ \\
\hline $\begin{array}{l}\text { Scheltens P, } 2012 \\
{[39]} \\
\text { Souvenir II } \\
\text { Randomized } \\
\text { controlled trial }\end{array}$ & $\begin{array}{l}259 \text { drug-naive } \\
\text { individuals with } \\
\text { mild AD aged } 50 \\
\text { years or older. }\end{array}$ & $\begin{array}{l}125 \mathrm{ml} \text { of } \\
\text { Souvenaid was } \\
\text { taken daily }\end{array}$ & 24 weeks & $\begin{array}{l}\text { Souvenaid supplementation had a } \\
\text { beneficial effect on subjects NTB } \\
\text { memory domain Z-scores, and one } \\
\text { of four measures of functional } \\
\text { brain connectivity based on EEG } \\
\text { analysis. No difference was seen } \\
\text { between groups in three of four } \\
\text { measures of functional brain } \\
\text { connectivity, or NTB executive } \\
\text { function domain Z-scores. }\end{array}$ \\
\hline $\begin{array}{l}\text { Shah RC, } 2013 \\
\text { [40] } \\
\text { Randomized } \\
\text { controlled trial }\end{array}$ & $\begin{array}{l}527 \text { individuals } \\
\text { diagnosed with mild } \\
\text { to moderate AD, } \\
\text { taking AD } \\
\text { medications. }\end{array}$ & $\begin{array}{l}125 \mathrm{ml} \text { of } \\
\text { Souvenaid was } \\
\text { taken daily }\end{array}$ & 24 weeks & $\begin{array}{l}\text { ADAS-cog scores determined } \\
\text { Souvenaid treatment had no } \\
\text { beneficial effect on cognition } \\
\text { compared to placebo. }\end{array}$ \\
\hline
\end{tabular}

Souvenaid ingredients: EPA (300mg), DHA (1200mg), Phospholipids (106mg), Choline (400mg), Uridine (625mg), Vitamin E (40mg), Vitamin C (80mg), Vitamin B6 (1mg), Vitamin B12 $(3 \mu \mathrm{g})$, Selenium $(60 \mu \mathrm{g})$, and Folic acid $(400 \mu \mathrm{g})$ [41].

\section{DISCUSSION}

Throughout the reviewed vitamin B trials, the most beneficial effects on measures of cognition were seen in a subgroup within the VITACOG sample that studied participants with higher than median baseline plasma tHcy levels [27]. Within this subgroup, vitamin B supplementation improved memory, global cognitive function and clinical status. The other vitamin B trials reviewed did not define baseline plasma tHcy subgroups, and vitamin B had no beneficial effects on measures of overall cognitive ability independent of baseline plasma tHcy levels [29, 30]. B 
vitamin supplementation had a beneficial effect on measures of neurodegeneration via rates of brain atrophy in the VITACOG trial [26, 28]. Future studies will need to replicate the VITACOG trial results in additional sample populations, before vitamin B's effect on brain atrophy can be considered conclusive. Throughout the Omega-3 fatty acid clinical trials, supplementation had a beneficial effect on measures of both overall cognitive ability and specific cognitive function in participants with lower levels of baseline cognitive impairment [34, 35]. Omega-3 fatty acid supplementation did not elicit any beneficial effects on measures of overall cognitive ability, independent of baseline cognitive impairment [31-36]. There were reports of improvements in specific cognitive function examinations from Omega-3 supplementation independent of baseline cognitive impairment, but no single report was replicated by another study [31-36]. The clinical trials that utilized the Fortasyn Connect nutrient combination via the medical food Souvenaid, showed that supplementation provided a beneficial effect on one of four measures of functional brain connectivity, and two separate memory examinations [38, 39]. Souvenaid was not associated with similar positive effects on scores of overall cognition and or other measures of functional brain connectivity [38, 40].

Supplementation with vitamin B, Omega-3 fatty acids, or bioactive compounds in Fortasyn Connect was not conclusively proven to have a beneficial effect on $\mathrm{AD}$ or MCI patient cognitive outcomes, and there is not enough data to conclude an effect on measures of neurodegeneration. Despite this determination, several positive effects from bioactive compound supplementation have been seen within individual studies, justifying further investigation. Potential topics of further investigation include, the effect of bioactive compounds on $\mathrm{AD}$ and MCI patients with higher baseline plasma tHcy levels, and lower baseline levels of cognitive impairment, and the effects of vitamin B supplementation on rates brain atrophy in patients with MCI.

\section{Considerations for Functional Food Development}

The results of these bioactive compound clinical trials are of primary importance to the field of functional food science because a core objective of functional food research is to substantiate the effects of bioactive compounds. The Functional Food Center, based in the United States, has comprehensively defined a functional food as, "Natural or processed foods that contains known or unknown biologically-active compounds; which, in defined, effective non-toxic amounts, provide a clinically proven and documented health benefit for the prevention, management, or treatment of chronic disease" [42]. Although previously specified quantities of vitamin B, Omega-3 fatty acids, and bioactive compounds in Fortasyn Connect have proven to be non-toxic throughout the reviewed studies, their clinical efficacy to manage AD or MCI remains unproven. For this reason, we do not recommend that these clinically tested quantities of bioactive compounds be considered for development of a functional food.

\section{CONCLUSION}

The results of clinical trials within the last 15 years do not conclusively prove that the specified quantities of vitamin B, Omega-3 fatty acids, or bioactive compounds within Fortasyn Connect, are beneficial for use in the management of AD or MCI. Additionally, the documented effects of these bioactive compounds do not warrant development of a functional food product utilizing the previously specified quantities to help manage $\mathrm{AD}$ or MCI. The effects bioactive compound 
supplementation had on measures of neurodegeneration, and cognition in individuals with higher levels of baseline plasma tHcy and lower levels of cognitive impairment warrants further investigation.

List of Abbreviations: Alzheimer's Disease, AD; Mild Cognitive Impairment, MCI; Homocysteine, tHcy; Amyloid Beta, A $\boldsymbol{\beta}$; Neurofibrillary tangles, NFT; Mini-Mental State Examination, MMSE; Mini-Mental State Examination Serial Sevens, MMSES7; Mini-Mental State Examination World Backwards, MMSEWB; Alzheimer's Disease Assessment ScaleCognitive subscale, ADAS-cog; Magnetic Resonance Imaging, MRI; Docosahexanoic acid, DHA; Eicosapentaenoic acid, EPA; Cognitive Impairment No Dementia, CIND; Omega-3 fatty acids, Omega-3; Randomized Controlled Trial, RCT; Neuropsychological Test Battery, NTB; Electroencephalography, EEG; Clinical Dementia Rating, CDR; Informant Questionnaire on Cognitive Decline in the Elderly, IQCODE; Clinicians Global Impression of Change, CIBICplus; Activities of Daily Living, ADL; Alzheimer's Disease Cooperative Study Activities of Daily Living, ADCS-ADL; Instrumental Activities of Daily Living, IADL; Hamilton Depression Rating Scale, HDRS; Clock-Drawing Test, CDT; Global Deterioration Scale, GDS; Rey Auditory Verbal Learning Test, RAVLT.

Competing Interests: The authors have no financial interests or any other conflicts of interest to disclose.

Authors' Contributions: All authors contributed to this review

\section{REFERENCES:}

1. World Alzheimer Report 2015: The Global Impact of Dementia, an analysis of prevalence, incidence, cost and trends. Alzheimer's Disease International. 2015; [http://www.alz.co.uk/research/WorldAlzheimerReport2015.pdf]

2. Tarawneh R, Holtzman DM: The Clinical Problem of Symptomatic Alzheimer Disease and Mild Cognitive Impairment. Cold Spring Harbor Perspectives in Medicine. 2012; 2(5).

3. GBD 2013 Mortality and Causes of Death Collaborators: Global, regional, and national age-sex specific all-cause and cause-specific mortality for 240 causes of death, 1990-2013: a systematic analysis for the Global Burden of Disease Study 2013. Lancet. 2015; 385(9963):117-17.

4. Vega JN, Newhouse PA: Mild Cognitive Impairment: Diagnosis, Longitudinal Course, and Emerging Treatments. Current psychiatry reports. 2014; 16(10).

5. Mufson EJ, Binder L, Counts SE, et al: Mild Cognitive Impairment: Pathology and mechanisms. Acta Neuropathologica. 2012; 123(1):13-30.

6. Engelhart MJ, Geerlings MI, Ruitenberg A, van Swieten JC, Hofman A, Witteman JCM, Breteler MMB: Diet and risk of dementia: Does fat matter? The Rotterdam Study. Neurology. 2002; 59:1915-1921. 
7. Arioğul S, Cankurtaran M, Dağli N, Khalil M, Yavuz B: Vitamin B12, folate, homocysteine and dementia: are they really related? Archives of Gerontology and Geriatrics. 2005; 40(2):139-146.

8. Devore EE, Grodstein F, van Rooij FJ, et al: Dietary intake of fish and omega-3 fatty acids in relation to long-term dementia risk. The American Journal of Clinical Nutrition. 2009; 90(1):170-176.

9. Hippius H, Neundörfer G: The discovery of Alzheimer's disease. Dialogues in Clinical Neuroscience. 2003; 5(1):101-108.

10. Niedowicz DM, Nelson PT, Murphy MP: Alzheimers Disease: Pathological Mechanisms and Recent Insights. Curr Neuropharmacol. 2011; 9(4):674-684.

11. Mufson EJ, Binder L, Counts SE, et al: Mild Cognitive Impairment: Pathology and mechanisms. Acta Neuropathologica. 2012; 123(1):13-30.

12. Crews L, Masliah E: Molecular mechanisms of neurodegeneration in Alzheimer's disease. Human Molecular Genetics. 2010; 19(R1):R12-R20.

13. Guerrero-Muñoz MJ, Castillo-Carranza DL, Kayed R: Therapeutic approaches against common structural features of toxic oligomers shared by multiple amyloidogenic proteins. Biochemical Pharmacology. 2014; 88(4):468-478.

14. Kolarova M, García-Sierra F, Bartos A, Ricny J, Ripova D: Structure and Pathology of Tau Protein in Alzheimer Disease. International Journal of Alzheimer's Disease. 2012; 2012:731526.

15. Gerson JE, Kayed R: Formation and Propagation of Tau Oligomeric Seeds. Frontiers in Neurology. 2013; 4:93.

16. Ballatore C, Lee VM-Y, Trojanowski JQ: Tau-mediated neurodegeneration in Alzheimer's disease and related disorders. Nature Reviews Neuroscience Nat Rev Neurosci. 2007; 8(9):663-672.

17. Šimić G, Leko MB, Wray S, et al: Tau Protein Hyperphosphorylation and Aggregation in Alzheimer's Disease and Other Tauopathies, and Possible Neuroprotective Strategies. Biomolecules. 2016; 6(1):6.

18. Wolfe MS: The Role of Tau in Neurodegenerative Diseases and Its Potential as a Therapeutic Target. Scientifica. 2012; 2012:1-20.

19. Gendron TF, Petrucelli L: The role of tau in neurodegeneration. Molecular Neurodegeneration. 2009; 4:13.

20. van Wijk N, Broersen LM, de Wilde MC, Hageman RJ, Groenendijk M, Sijben JW, Kamphuis PJ: Targeting synaptic dysfunction in Alzheimer's disease by administering a specific nutrient combination. J Alzheimers Dis. 2014; 5:459-479.

21. Thaipisuttikul P, Galvin JE: Use of medical foods and nutritional approaches in the treatment of Alzheimer's disease. Clinical practice (London, England). 2012; 9(2):199-209.

22. Sheehan B: Assessment scales in dementia. Therapeutic Advances in Neurological Disorders. 2012; 5(6):349-358. 
23. Podhorna J, Krahnke T, Shear M, E Harrison J: Alzheimer's Disease Assessment Scale-Cognitive subscale variants in mild cognitive impairment and mild Alzheimer's disease: change over time and the effect of enrichment strategies. Alzheimer's Research \& Therapy. 2016; 8(1):8.

24. Johnson KA, Fox NC, Sperling RA, Klunk WE: Brain Imaging in Alzheimer Disease. Cold Spring Harbor Perspectives in Medicine. 2012; 2(4).

25. Frisoni GB, Fox NC, Jack CR, Scheltens P, Thompson PM: The clinical use of structural MRI in Alzheimer disease. Nature reviews Neurology. 2010; 6(2):67-77.

26. Smith AD, Smith SM, de Jager CA, et al: Homocysteine-Lowering by B Vitamins Slows the Rate of Accelerated Brain Atrophy in Mild Cognitive Impairment: A Randomized Controlled Trial. Bush AI, ed. PLoS ONE. 2010; 5(9).

27. de Jager CA, Oulhaj A, Jacoby R, Refsum H, Smith AD: Cognitive and clinical outcomes of homocysteine-lowering B-vitamin treatment in mild cognitive impairment: A randomized controlled trial. Int J Geriatr Psychiatry. 2012; 27(6):592600 .

28. Douaud G, Refsum H, Jager CAD, et al: Preventing Alzheimer's disease-related gray matter atrophy by B-vitamin treatment. Proceedings of the National Academy of Sciences Proc Natl Acad Sci USA. 2013; 110(23):9523-9528.

29. Aisen PS, Schneider LS, Sano M, et al: High Dose B Vitamin Supplementation and Cognitive Decline in Alzheimer's Disease: A Randomized Controlled Trial. JAMA: the journal of the American Medical Association. 2008; 300(15):1774-1783.

30. van Uffelen J, Chinapaw M, van Mechelen W, Hopman-Rock M: Walking or vitamin B for cognition in older adults with mild cognitive impairment? A randomised controlled trial. British Journal Of Sports Medicine [serial online]. May 2008; 42(5):344-351.

31. Quinn JF, Raman R, Thomas RG, et al: Docosahexaenoic Acid Supplementation and Cognitive Decline in Alzheimer Disease. Jama. 2010; 304(17):1903.

32. Phillips M, Childs C, Calder P, Rogers P: No Effect of Omega-3 Fatty Acid Supplementation on Cognition and Mood in Individuals with Cognitive Impairment and Probable Alzheimer's Disease: A Randomised Controlled Trial. IJMS International Journal of Molecular Sciences. 2015; 16(10):24600-24613.

33. Lee LK, Shahar S, Chin A-V, Yusoff NAM: Docosahexaenoic acid-concentrated fish oil supplementation in subjects with mild cognitive impairment (MCI): a 12-month randomised, double-blind, placebo-controlled trial. Psychopharmacology. 2012; 225(3):605-612.

34. Freund-Levi Y, Eriksdotter-Jönhagen M, Cederholm T, et al: $\omega-3$ Fatty Acid Treatment in 174 Patients With Mild to Moderate Alzheimer Disease: OmegAD Study. Arch Neurol Archives of Neurology. 2006; 63(10):1402.

35. Chiu C-C, Su K-P, Cheng T-C, et al: The effects of omega-3 fatty acids monotherapy in Alzheimer's disease and mild cognitive impairment: A preliminary randomized 
double-blind placebo-controlled study. Progress in Neuro-Psychopharmacology and Biological Psychiatry. 2008; 32(6):1538-1544.

36. Shinto L, Quinn J, Montine T, et al: A Randomized Placebo-Controlled Pilot Trial of Omega-3 Fatty Acids and Alpha Lipoic Acid in Alzheimer's Disease. Journal of Alzheimer's disease: JAD. 2014; 38(1).

37. Olde Rikkert MGM, Verhey FR, Blesa R, von Arnim CAF, Bongers A, Harrison J, et al: Tolerability and safety of Souvenaid in patients with mild Alzheimer's disease: results of multi-center, 24-week, open-label extension study. J Alzheimers Dis. 2015; 44:471-80.

38. Scheltens P, Kamphuis PJ, Verhey FR, et al: Efficacy of a medical food in mild Alzheimer's disease: A randomized, controlled trial. Alzheimer's \& Dementia. 2010; 6(1).

39. Scheltens P, Twisk JW, Blesa R, Scarpini E, von Arnim CA, Bongers A, et al: Efficacy of Souvenaid in mild Alzheimer's disease: results from a randomized, controlled trial. J Alzheimers Dis. 2012; 31:225-36.

40. Shah RC, Kamphuis PJ, Leurgans S, et al: The S-Connect study: results from a randomized, controlled trial of Souvenaid in mild-to-moderate Alzheimer's disease. Alzheimers Res Ther Alzheimer's Research \& Therapy. 2013; 5(6):59.

41. What is Souvenaid®. [https://www.mysouvenaid.co.uk/what-is-souvenaid/ingredients]

42. Martirosyan DM, Singh J: A new definition of functional food by FFC: what makes a new definition unique? Functional Foods in Health and Disease. 2015; 5(6):209-223. 